\title{
Short-term relationships between plasma LH, FSH and progesterone concentrations in post-partum dairy cows and the effect of Gn-RH injection
}

\author{
J. P. Foster, G. E. Lamming and A. R. Peters \\ Department of Physiology and Environmental Studies, University of Nottingham School of \\ Agriculture, Sutton Bonington, Loughborough, Leicestershire, LE12 5RD, U.K.
}

\begin{abstract}
Summary. Jugular venous blood samples were obtained from 7 dairy cows every 10 min for 10-19 h during the early- or mid-luteal phase of the oestrous cycle, and each cow was given 1 or 2 i.v. injections of $100 \mu \mathrm{g}$ synthetic Gn-RH. Four of these cows were also sampled in a different cycle with no treatment being administered. Peaks of plasma LH, FSH and progesterone were detected in each animal in the absence of treatment; those of $\mathrm{LH}$ and progesterone often occurred in parallel. Injection of Gn-RH was always followed by a significant increase in plasma LH and progesterone concentrations and in most cases by a significant FSH increase. There was a significant temporal relationship between the peaks of all 3 hormones.

A further 8 cows were sampled during the first 10 days post partum when the mean plasma progesterone concentration was low. An i.v. injection of $200 \mu \mathrm{g}$ synthetic Gn-RH was given to each animal and this resulted in a significant increase in plasma $\mathrm{LH}$ and FSH concentrations, but in only one cow was the Gn-RH injection followed by a significant increase in plasma progesterone concentration. The $\mathrm{LH}$ response to $\mathrm{Gn}-\mathrm{RH}$ injection was significantly less in cows injected on or before Day 5 post partum than in cows injected on Days 7-10 post partum.
\end{abstract}

\section{Introduction}

Study of the relationship between plasma concentrations of reproductive hormones during the post-partum period of the dairy cow provides information about the control of ovarian activity and the transition from anoestrus to resumption of ovarian cycles.

Plasma luteinizing hormone (LH) and progesterone concentrations have usually been measured in samples taken at daily or longer intervals during the post-partum period of cows (Schams, Hoffmann, Fischer, Marz \& Karg, 1972; Edgerton \& Hafs, 1973; Gaverick, Brady, Mather, Bierschwal \& Erb, 1973; Smith, Edgerton, Hafs \& Convey, 1973; Arije, Wiltbank \& Hopwood, 1974; Corah, Quealy, Dunn \& Kaltenbach, 1974; Dickey, Henricks \& Bierly, 1975), but we have reported studies on animals sampled at 6-h intervals from calving until 35 days post partum (Lamming, 1978; Webb, Lamming, Haynes \& Foxcroft, 1980), a technique also used by Schams et al. (1978). Measurement of follicle-stimulating hormone (FSH) has also been carried out (Akbar, Reichert, Dunn, Kaltenbach \& Niswender, 1974; Dobson, 1978; Webb et al., 1980). To the best of our knowledge no studies have yet been reported in which short-term variations in the plasma levels of these 3 hormones have been measured concurrently in cattle, although Baird, Swanston \& Scaramuzzi (1976) and Scaramuzzi \& Baird (1979) have measured plasma $\mathrm{LH}$ and oestradiol- $17 \beta$ respectively in cyclic and seasonally anoestrous sheep at 10-min 
intervals and found that each peak of $\mathrm{LH}$ release was followed by a rise in oestradiol concentrations.

The present study was undertaken (1) to examine the short-term relationship between $\mathrm{LH}$, FSH and progesterone in cyclic dairy cows when luteal tissue was known to be present, and (2) to compare these hormone patterns in normal cyclic animals with those in anoestrous cows during the early post-partum period. Gonadotrophin-releasing hormone (Gn-RH) causes LH and FSH release in anoestrous and cyclic cows (see Akbar et al., 1974) and has been reported to cause progesterone release in cows injected during the luteal phase of the oestrous cycle (Kittock, Britt \& Convey, 1973; Zolman, Convey \& Britt, 1974). We therefore investigated the effect of $\mathrm{Gn}-\mathrm{RH}$ on the 3 hormones being studied.

\section{Materials and Methods}

Friesian dairy cows in their second or third lactation were used. They were machine milked twice daily and fed a high quality dairy ration according to yield. Milk samples were collected from each cow 3 times weekly and assayed for progesterone concentration to monitor ovarian cycles. All blood samples were taken via an indwelling jugular catheter.

\section{Experimental design}

Cyclic cows. Seven (7) autumn-calving cows were used between 22 and 105 days post partum. Cows 1-3 were sampled during the mid-luteal phase of the oestrous cycle (7-14 days after the beginning of the milk progesterone rise, i.e. assumed to be Days 11-18 of cycle) as follows. Blood samples were taken every $10 \mathrm{~min}$ for $8 \mathrm{~h}, 100 \mu \mathrm{g}$ synthetic Gn-RH (Lutal: Hoechst, Frankfurt, West Germany) were then injected i.v. and the animals were sampled every $10 \mathrm{~min}$ for a further $11 \mathrm{~h}$ with a second $\mathrm{Gn}-\mathrm{RH}$ injection administered $6 \mathrm{~h}$ after the first. Cows 4-7 were sampled every $10 \mathrm{~min}$ in the luteal phase for periods of 4-6 h, then injected i.v. with $100 \mu \mathrm{g} \mathrm{Gn}-\mathrm{RH}$ and sampled at 10-min intervals for a further $6 \mathrm{~h}$. Cows 4 and 5 were in the early luteal phase (1-6 days after the start of the progesterone rise) and Cows 6 and 7 were mid-luteal.

Cows 4-7 were also sampled for 5-8 h during a different cycle when they were in the early luteal (Cows 4 and 5) or mid-luteal (Cows 6 and 7) phase but no treatment was administered.

Post-partum anoestrous cows. Eight (8) autumn-calving cows (Nos 8-15) were sampled every $10 \mathrm{~min}$ for $4 \mathrm{~h}$ before and for $10 \mathrm{~h}$ after a single i.v. injection of $200 \mu \mathrm{g}$ synthetic $\mathrm{Gn}-\mathrm{RH}$ (Hoechst) during the first 10 days post partum. Cows 8-11 were sampled on Days 4 or 5 post partum and Cows $12-15$ on Days 7-10. Blood samples $(5 \mathrm{ml})$ were collected in heparinized tubes and centrifuged at $1500 \mathrm{~g}$ for $15 \mathrm{~min}$. The plasma was removed and stored at $-20^{\circ} \mathrm{C}$ until assayed.

\section{Hormone assays}

All hormones were measured by radioimmunoassay procedures in routine use in this laboratory. Plasma LH (reference standard NIH-LH-B9) and progesterone levels were assayed as described by Webb, Lamming, Haynes, Hafs \& Manns (1977). The intra- and inter-assay coefficients of variation (CVs) for the $\mathrm{LH}$ assay were 6.5 and $8.0 \%$ respectively and the sensitivity was $0.15 \mathrm{ng} / \mathrm{ml}$. For the progesterone assay, the mean recovery was $64.1 \pm 2 \cdot 3 \%$ $(n=14)$ and values were corrected accordingly. The intra- and inter-assay CVs were 4.8 and $11.3 \%$ respectively and the sensitivity was $25 \mathrm{pg} /$ tube. Plasma FSH was measured using the heterologous system described by Webb et al. (1980) with reference standard NIH-FSH-B1. The intra- and inter-assay CVs were 8.3 and $12.0 \%$ respectively, and the sensitivity was 9.0 $\mathrm{ng} / \mathrm{ml}$. Milk progesterone was assayed by the method of Lamming \& Bulman (1976). The intraand inter-assay CVs were 8.9 and $10.3 \%$ respectively and the sensitivity was $0.4 \mathrm{ng} / \mathrm{ml}$. 
For each animal the mean LH, FSH and progesterone concentrations were determined for the entire sampling period for the untreated animals and for the period before injection of $\mathrm{Gn}-\mathrm{RH}$ for the treated animals. Values greater than 2 standard deviations above these means were taken as being significantly greater than the mean.

\section{Results}

\section{Cyclic cows}

The changes in Cows 1 and 2 before and after injection of synthetic $\mathrm{Gn}-\mathrm{RH}$ in the mid-luteal phase are shown in Text-fig. 1. Significant elevations of all 3 hormones occurred in all 7 cows in the absence of any treatment and injection of synthetic $\mathrm{Gn}-\mathrm{RH}$ was always followed by a significant increase in $\mathrm{LH}$ and progesterone concentrations. Plasma FSH concentrations sometimes increased significantly after injection. There was no difference between the early and mid-luteal phases of the oestrous cycle in the responses obtained.

Progesterone peaks were often associated with $\mathrm{LH}$ peaks in the absence of treatment and sometimes also with FSH peaks. In only one instance (Cow 6) was a progesterone peak associated with an FSH peak but not an LH peak. Each progesterone value in the control and treated periods was categorized according to whether it was significantly greater than the mean progesterone concentration in that animal and to its relationship with significant $\mathrm{LH}$ and FSH increases (Table 1). A $\chi^{2}$ analysis of the pooled $\mathrm{LH}$ and progesterone data indicated that there was a temporal relationship between significant increases in plasma $\mathrm{LH}$ and progesterone concentrations $\left(\chi^{2}=77.6, P<0.001\right)$. There was a greater correspondence of progesterone increases with the LH increases than would be expected if there were no relationship between the two. There was also a significant relationship between significant increases in plasma FSH and progesterone concentration $\left(\chi^{2}=30 \cdot 2, P<0.01\right)$.

Table 1. Occurrence of plasma samples with increased progesterone concentrations/total number of samples in relation to $\mathrm{LH}$ and $\mathrm{FSH}$ peaks

\begin{tabular}{|c|c|c|}
\hline \multirow{2}{*}{$\begin{array}{l}\text { Time when progesterone } \\
\text { conc. significantly } \\
>\text { mean value }\end{array}$} & \multicolumn{2}{|c|}{ Significant peaks of: } \\
\hline & LH & FSH \\
\hline $\begin{array}{l}\text { During } \\
\text { After }\end{array}$ & $64 / 163(62.7 \%)^{*}$ & $18 / 43 \quad(17 \cdot 7 \%)$ \\
\hline $0-1 \mathrm{~h}$ & $12 / 92 \quad(11.8 \%)$ & $29 / 108(28.4 \%)$ \\
\hline $1-3 \mathrm{~h}$ & $17 / 99 \quad(16 \cdot 7 \%)$ & $16 / 122(15.7 \%)$ \\
\hline Unrelated & $9 / 246(8.8 \%)$ & $39 / 327(38.2 \%)$ \\
\hline Total & $102 / 600$ & $102 / 600$ \\
\hline
\end{tabular}

\footnotetext{
* Calculated as $64 / 102$, i.e. $62.7 \%$ of significant progesterone increases occurred during significant $\mathrm{LH}$ increases which occupied $163 / 600(27 \%)$ of the sampling time.
}

Additionally, there was a relationship between significant increases in plasma LH and FSH concentration since $79 \%$ of all samples with significantly elevated FSH were taken during or within $1 \mathrm{~h}$ of a significant increase in plasma LH. The plasma concentrations of both gonadotrophins usually increased significantly after synthetic Gn-RH injection (although in 2 cyclic cows FSH did not increase). At other times, peaks of the 2 hormones were unrelated.

\section{Anoestrous cows}

In 7 of the 8 animals injected during the first 10 days post partum the plasma progesterone concentration was low $(<0.05 \mathrm{ng} / \mathrm{ml})$ and although $\mathrm{Gn}-\mathrm{RH}$ injection was always followed by a significant increase in plasma LH and FSH concentration there were no significant changes in 

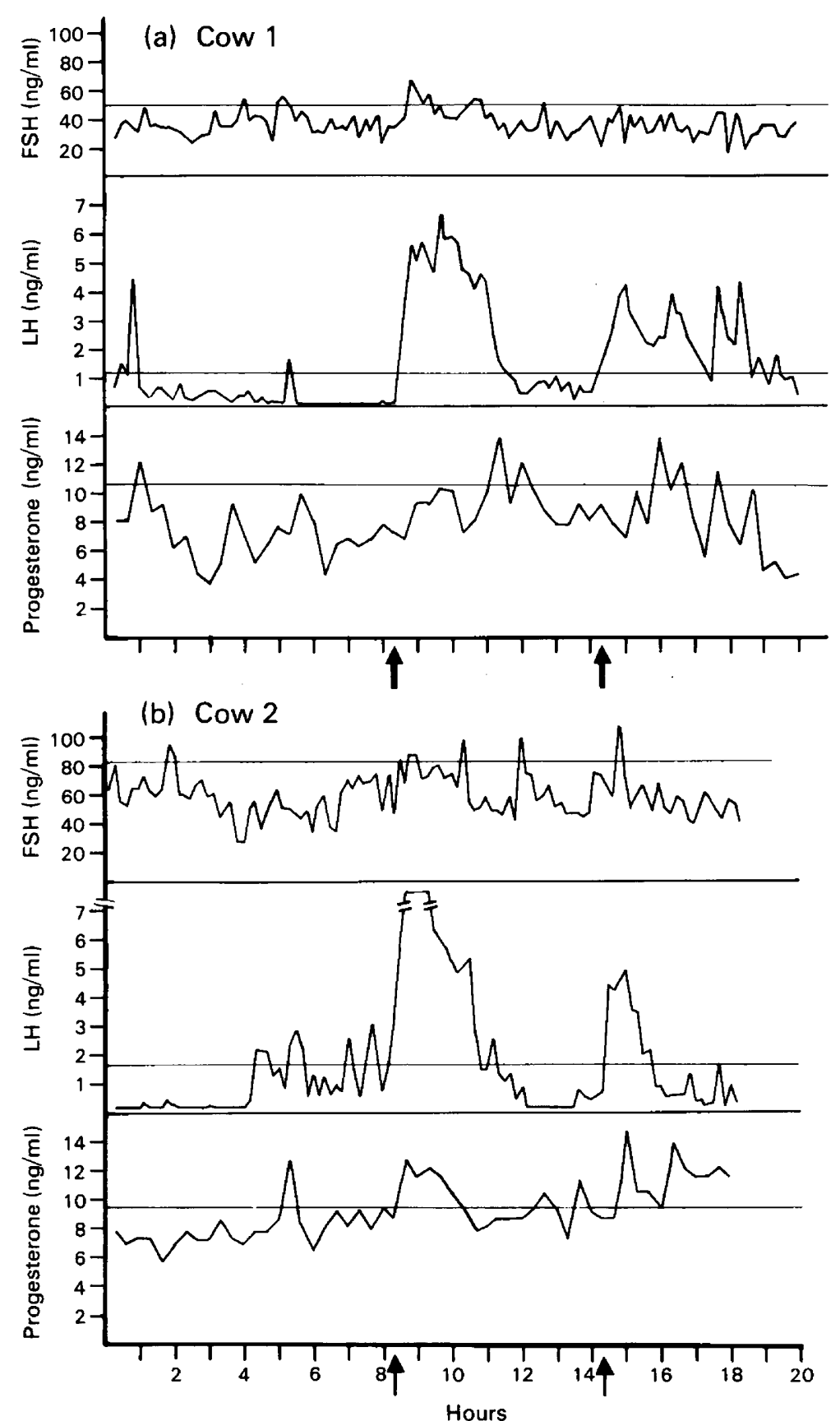

Text-fig. 1. Plasma hormone concentrations in (a) Cow 1 and (b) Cow 2, sampled during the mid-luteal phase of the oestrous cycle. The arrows indicate the time of injection of synthetic Gn-RH. Horizontal lines indicate 2 standard deviations above the mean pre-injection value, and all values above these lines are considered to be significant peaks.

progesterone concentration (Text-fig. 2a). However, in Cow 15 (Text-fig. 2b) there was a significant increase, lasting $2.3 \mathrm{~h}$, in plasma progesterone concentration $4.5 \mathrm{~h}$ after $\mathrm{Gn}-\mathrm{RH}$ injection. The mean plasma $\mathrm{LH}(1.7 \mathrm{ng} / \mathrm{ml})$ and progesterone $(0.56 \mathrm{ng} / \mathrm{ml})$ concentrations in 
this cow before Gn-RH injection were greater than those of the other animals in this group (LH $0.2-0.89 \mathrm{ng} / \mathrm{ml}$; progesterone $<0.1-0.38 \mathrm{ng} / \mathrm{ml}$ ) and significant fluctuations in concentration were observed only in this animal. When the response to Gn-RH injection was assessed in terms of area under the induced LH and FSH peaks, the LH response in Cow $15\left(12793 \mathrm{~mm}^{2}\right)$ was greater than that of the other animals $\left(1665-8047 \mathrm{~mm}^{2}\right)$ and the FSH response $\left(5424 \mathrm{~mm}^{2}\right)$ was the second highest of the group $\left(1140-6156 \mathrm{~mm}^{2}\right)$. Cow 15 began to cycle within 6 days of treatment (as indicated by an increase in milk progesterone concentration) whereas none of the other cows ovulated within 16 days of treatment.
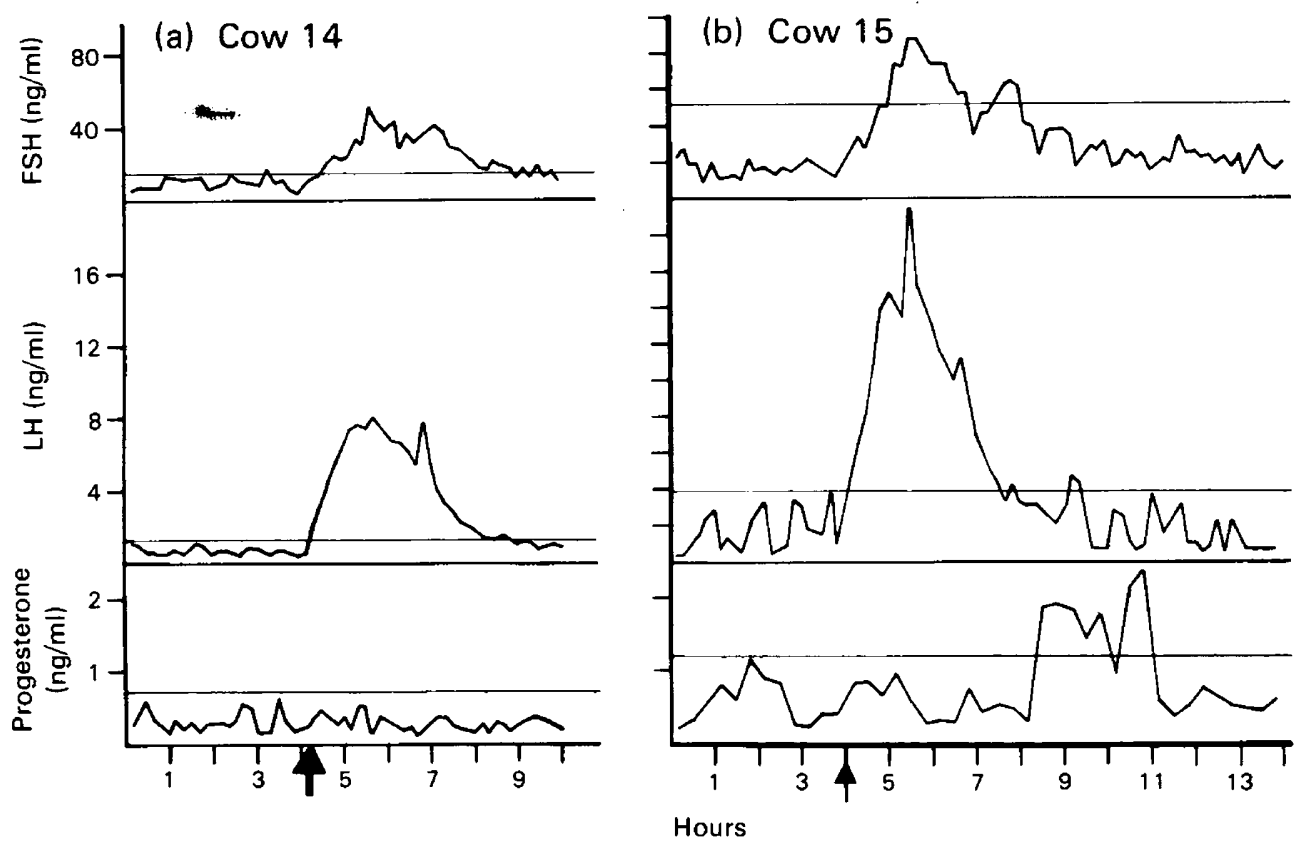

Text-fig. 2. Plasma hormone concentrations in (a) Cow 14 and (b) Cow 15 sampled on Day 10 post partum. The arrow indicates the time of injection of synthetic Gn-RH. Cow 14 was typical of $7 / 8$ of the cows studied but Cow 15 was the only one in which a significant increase in plasma progesterone was obtained in response to the Gn-RH. Horizontal lines indicate 2 standard deviations above the mean pre-injection value, and all values above these lines are considered to be significant peaks.

The 4 cows injected on or before Day 5 post partum had a significantly lower LH response to $\mathrm{Gn}-\mathrm{RH}$ (mean \pm s.e.m. area of induced peak $3091 \pm 499 \mathrm{~mm}^{2}$ ) than the 4 cows injected on Days 7-10 post partum $\left(8841 \pm 2090 \mathrm{~mm}^{2}\right)$. There was, however, no difference between these times in the FSH response (Day 5 mean area $3891 \pm 958 \mathrm{~mm}^{2}$; Day 7-10 mean area $2715 \pm$ $992 \mathrm{~mm}^{2}$ ).

\section{Discussion}

The short duration of the hormone peaks measured in these animals (often less than $30 \mathrm{~min}$ ) emphasizes the importance of frequent sampling for studies of this type. Although in dairy cows with a functional corpus luteum there was a significant temporal relationship between plasma peaks of FSH and progesterone as well as of LH and progesterone, the latter correspondence was more marked. The relationship between FSH and progesterone may be indirect, occurring because the release of $\mathrm{LH}$ is related to that of FSH, and the immediate increase in progesterone following Gn-RH injection in cows with a functional corpus luteum is probably due to stimulation by $\mathrm{LH}$ rather than FSH. A positive relationship between $\mathrm{LH}$ and progesterone 
release has been reported in vitro (Armstrong \& Black, 1966; Seifart \& Hansel, 1968) and passive immunization studies have suggested that $\mathrm{LH}$ is the main luteotrophic factor in the cow (Hoffmann et al., 1974).

The lack of progesterone response to injection of $\mathrm{Gn}-\mathrm{RH}$ in all but one of the anoestrous cows suggests that luteal tissue has to be present for such a response to be elicited. The one animal that did respond to $\mathrm{Gn}-\mathrm{RH}$ had a higher pre-treatment plasma level of progesterone and $\mathrm{LH}$ and a higher pituitary responsiveness to $\mathrm{Gn}-\mathrm{RH}$ than did the others in this group. In many animals there is an elevated plasma progesterone concentration before the first post-partum ovulation (see Donaldson, Bassett \& Thorburn, 1970; Robertson, 1972; Humphrey, Koritnik, Kaltenbach, Dunn \& Niswender, 1976; Lamming \& Bulman, 1976; Lavoie \& Moody, 1976; Lamming, 1978) which may be associated with changes in gonadotrophin secretion. This was probably the situation in this particular cow since it began to show ovarian cycles within 6 days of treatment. If this is so, then it is tempting to speculate that there was luteal tissue present in the ovaries of this animal at the time of treatment, i.e. before the first ovulation. Rectal examination of other anoestrous cows after parturition has revealed the presence of small palpable ovarian structures concurrent with small increases in milk progesterone concentration before the first post-partum ovulation (A. R. Peters \& J. P. Foster, unpublished observation). These structures were no longer palpable after the milk progesterone concentration had decreased to basal values. It may be possible to demonstrate the presence of luteal tissue in bovine ovaries by a positive progesterone response to $\mathrm{Gn}-\mathrm{RH}$ injection.

The lack of an ovulatory response to Gn-RH in most of the anoestrous dairy cows is probably due to the early time post partum at which they were injected. The pituitary LH response to $\mathrm{Gn}-\mathrm{RH}$ is reported to be low in the first few days post partum and to increase thereafter (Lamming, 1978; Schallenberger, Schams \& Zoltmeier, 1978) and this was confirmed in these animals. This increase in LH responsiveness to $\mathrm{Gn}-\mathrm{RH}$ during the first 10 days post partum may be responsible for the increase in endogenous $\mathrm{LH}$ release which occurs at this time (unpublished data).

The relationship between peaks of LH and FSH is not as clear-cut as might perhaps be expected if these two hormones are released by the same releasing hormone. Separate mechanisms may therefore operate for at least the tonic release of LH and FSH. In the mare, the LH/FSH response ratio to exogenous Gn-RH changes significantly during the oestrous cycle (Foster, Evans \& Irvine, 1979) and a different LH and FSH release pattern could therefore be explained by the different way in which pituitary gonadotrophs respond to a common releasing hormone.

The relationship between $\mathrm{LH}$ and progesterone is obviously important in the control of cow ovarian cycles; the stimulation of progesterone secretion by LH in animals with a corpus luteum provides an important luteotrophic influence. The results from early post-partum anoestrous cows suggest that LH is not capable of stimulating progesterone secretion at this stage but that it may be capable of doing so a few days before the first ovulation when responsive ovarian tissue is apparently present.

Studies of cyclic and seasonally anoestrous ewes have shown a close relationship between episodic release of LH and oestradiol-17ß (Baird et al., 1976; Scaramuzzi \& Baird, 1979), but a possible relationship between $\mathrm{LH}$ and progesterone in sheep during the luteal phase was not demonstrated. Since both prolactin and LH are necessary luteotrophins in sheep (Schroff, Klindt, Kaltenbach, Graber \& Niswender, 1971; Denamur, Martinet \& Short, 1973), it is possible that such a distinct relationship between progesterone and LH may not exist.

This work and J.P.F. were supported by a grant from the Agricultural Research Council, and A.R.P. was supported by a grant from the Meat and Livestock Commission. We thank Hoechst Pharmaceuticals and the NIH, U.S.A., for generous gifts of hormone preparations and Miss S. K. Lam and Mr P. J. L'Hermette for skilled technical assistance. 


\section{References}

Akbar, A.M., Reichert, L.E., Dunn, T.G., Kaltenbach, C.C. Niswender, G.D. (1974) Serum levels of follicle-stimulating hormone during the bovine estrous cycle. J. Anim. Sci. 39, 360-365.

Arije, G.R., Wiltbank, J.N. \& Hopwood, M.L. (1974) Hormone levels in pre- and post-parturient beef cows. J. Anim. Sci. 39, 338-347.

Armstrong, D.T. \& Black, D.L. (1966) Influence of luteinizing hormone on corpus luteum metabolism and progesterone biosynthesis throughout the bovine estrous cycle. Endocrinology 78, 937-944.

Baird, D.T., Swanston, I. \& Scaramuzzi, R.J. (1976) Pulsatile release of $\mathrm{LH}$ and secretion of ovarian steroids in sheep during the luteal phase of the estrous cycle. Endocrinology 98, 1490-1496.

Corah, L.R., Quealy, A.P., Dunn, T. G. \& Kaltenbach, C.C. (1974) Prepartum and postpartum levels of progesterone and estradiol in beef heifers fed two levels of energy. J. Anim. Sci. 39, 380-385.

Denamur, R.J., Martinet, J. \& Short, R.V. (1973) Pituitary control of the ovine corpus luteum. $J$. Reprod. Fert. 32, 207-220.

Dickey, J.F., Henricks, D.M. \& Bierly, S. (1975) Hormonal relationships in postpartum Holstein cows. J. Anim. Sci. 41, 348, Abstr.

Dobson, H. (1978) Radioimmunoassay of FSH in the plasma of post-partum dairy cows. J. Reprod. Fert. 52, 45-49.

Donaldson, L.E., Bassett, J.M. \& Thorburn, G.D. (1970) Peripheral plasma progesterone concentration of cows during puberty, oestrous cycles, pregnancy and lactation and the effects of undernutrition or exogenous oxytocin on progesterone concentrations. J. Endocr. 48, 599-614.

Edgerton, L.A. \& Hafs, H.D. (1973) Serum luteinizing hormone, prolactin, glucocorticoid and progestin in dairy cows from calving to gestation. J. Dairy Sci. 56, 451-458.

Foster, J.P., Evans, M.J. \& Irvine, C.H.G. (1979) Differential release of $\mathrm{LH}$ and FSH in cyclic mares in response to synthetic Gn-RH. J. Reprod. Fert. 56, $567-572$.

Gaverick, H.A., Brady, W.E., Mather, E.C., Bierschwal, C.J. \& Erb, R.E. (1973) Post-partum plasma hormone levels in dairy cows. J. Anim. Sci. 37, 311, Abstr.

Hofimann, B., Schams, D., Bopp, R., Ender, M.L., Giménez, T. \& Karg, H. (1974) Luteotrophic factors in the cow. Evidence for $\mathrm{LH}$ rather than prolactin. $J$. Reprod. Fert. 40, 77-85.

Humphrey, W.D., Koritnik, D.R., Kaltenbach, C.C., Dunn, T.G. \& Niswender, G.D. (1976) Progesterone and LH in post partum suckled beef cows. J. Anim. Sci. 43, 290, Abstr.

Kittock, R.J., Britt, J.H. \& Convey, E.M. (1973) Endocrine response after $\mathrm{Gn}-\mathrm{RH}$ in luteal phase cows and cows with ovarian follicular cysts. J. Anim. Sci. 37, 985-989.

Lamming, G.E. (1978) Reproduction during lactation. In Control of Ovulation, pp. 335-353. Eds D. B.
Crighton, G. R. Foxcroft, N. B. Haynes \& G. E. Lamming. Butterworths, London.

Lamming, G.E. \& Bulman, D.C. (1976) The use of milk progesterone radioimmunoassay in the diagnosis and treatment of subfertility in dairy cows. Br. vet. J. 132, 507-517.

Lavoie, V.L. \& Moody, E.L. (1976) Suckling effect on steroids in post partum cows. J. Anim. Sci. 43, 292-293.

Robertson, H.A. (1972) Sequential changes in plasma progesterone in the cow during the oestrous cycle, pregnancy, at parturition and post partum. Can. J. Anim. Sci. 52, 645-658.

Scaramuzzi, R.J. \& Baird, D.T. (1979) Ovarian steroid secretion in sheep during anoestrus. In Sheep Breeding, 2nd edn, pp. 463-470. Eds G. J. Tomes, D. E. Robertson \& R. J. Lightfoot (2nd edn, revised W. Haresign). Butterworths, London.

Schallenberger, E., Schams, D. \& Zoltmeier, K. (1978) Response of lutropin (LH) and follitropin (FSH) to the administration of gonadoliberin (Gn-RH) in pregnant and post partum cattle including experiments with prolactin suppression. Theriogenology 10 , 35-53.

Schams, D., Hoffmann, B., Fischer, S., Marz, E. \& Karg, H. (1972) Simultaneous determination of LH and progesterone in peripheral bovine blood during pregnancy, normal and corticoid-induced parturition and the post partum period. J. Reprod. Fert. 29, $37-48$.

Schams, D.E., Schallenberger, E., Menzer, Ch., Stangl, J., Zottmeier, K., Hoffmann, B. \& Karg, H. (1978) Profiles of LH, FSH and progesterone in postpartum dairy cows and their relationship to the commencement of cyclic functions. Theriogenology 10, 453-468.

Schroff, C., Klindt, J.M., Kaltenbach, C.C., Graber, J.W. \& Niswender, G.D. (1971) Maintenance of corpora lutea in hypophysectomized ewes. J. Anim. Sci. 33, 268.

Seifart, K.H. \& Hansel, W. (1968) Some characteristics and optimum incubation conditions of in vitro progesterone synthesis by bovine corpora lutea. Endocrinology 82, 232-240.

Smith, V.G., Edgerton, L.A., Hafs, H.D. \& Convey, E.M. (1973) Bovine serum estrogens, progestins and glucocorticoids during late pregnancy parturition and early lactation. J. Anim. Sci. 36, 391-396.

Webb, R., Lamming, G.E., Haynes, N.B., Hafs, H.D. \& Manns, J.G. (1977) Response of cyclic and postpartum suckled cows to injections of synthetic LH-RH. J. Reprod. Fert. 50, 203-210.

Webb, R., Lamming, G.E., Haynes, N.B. \& Foxcroft, G.R. (1980) Plasma progesterone and gonadotrophin concentrations and ovarian activity in post-partum dairy cows. J. Reprod. Fert. 59, 133-143.

Zolman, J., Convey, E.M. \& Britt, J.H. (1974) Relationships between the luteinizing hormone response to gonadotrophin releasing hormone and endogenous steroids. J. Anim. Sci. 39, 355-359. 